\title{
Beyond N-Cadherin, Relevance of Cadherins 5, 6 and 17 in Cancer Progression and Metastasis
}

\author{
J. Ignacio Casal * and Rubén A. Bartolomé
}

Department of Molecular Biomedicine, Centro de Investigaciones Biológicas (CIB)-Consejo Superior de Investigaciones Científicas (CSIC), Ramiro de Maeztu 9, 28039 Madrid, Spain

* Correspondence: icasal@cib.csic.es

Received: 30 May 2019; Accepted: 6 July 2019; Published: 9 July 2019

\begin{abstract}
Cell-cell adhesion molecules (cadherins) and cell-extracellular matrix adhesion proteins (integrins) play a critical role in the regulation of cancer invasion and metastasis. Although significant progress has been made in the characterization of multiple members of the cadherin superfamily, most of the published work continues to focus in the switch E-/N-cadherin and its role in the epithelial-mesenchymal transition. Here, we will discuss the structural and functional properties of a subset of cadherins (cadherin 17, cadherin 5 and cadherin 6) that have an RGD motif in the extracellular domains. This RGD motif is critical for the interaction with $\alpha 2 \beta 1$ integrin and posterior integrin pathway activation in cancer metastatic cells. However, other signaling pathways seem to be affected by RGD cadherin interactions, as will be discussed. The range of solid tumors with overexpression or "de novo" expression of one or more of these three cadherins is very wide (gastrointestinal, gynaecological and melanoma, among others), underscoring the relevance of these cadherins in cancer metastasis. Finally, we will discuss different evidences that support the therapeutic use of these cadherins by blocking their capacity to work as integrin ligands in order to develop new cures for metastatic patients.
\end{abstract}

Keywords: cadherin 17 (CDH17); VE-cadherin; cadherin 6 (CDH6); N-cadherin; $\alpha 2 \beta 1$ integrin; RGD motif; metastasis; therapeutic antibodies

\section{Introduction}

Metastasis initiation is enabled by cellular plasticity, including the mesenchymal-to-epithelial transition (MET) and the gain of stem-cell-like properties by cells in the metastatic organ site [1]. Organ-specific metastasis depends on different molecules, including growth factors, receptors, proteases, chemokines and cellular adhesion molecules, such as cadherins and integrins [2,3]. Cadherins are a major class of cell-cell adhesion molecules that regulate the adhesion and migration of cells in a calcium-dependent manner [4,5]. Cell-cell adhesion regulates cell polarity, cell differentiation and participates in the establishment of tissue homeostasis. Epithelial cadherin (E-cadherin, CDH1) is considered the prototype cadherin due to its early identification and exhaustive characterization [6]. It has been involved in stem cell maintenance and differentiation [7]. E-cadherin is considered to be a tumor suppressor involved in the epithelial-mesenchymal transition (EMT) [8]. During the EMT process, repression of E-cadherin by the transcription factor Snail and others (Slug, Zeb1, Zeb2) provokes the loss of the epithelial properties and a higher migration and invasion capacity of the cancer cells. EMT is characterized by the so-called "cadherin switch" between E-cadherin and the less adhesive neural cadherin ( $\mathrm{N}$-cadherin). Many cancer-related studies have mainly focused on this cadherin switch from E-cadherin, which is highly expressed in epithelial cells, to the $\mathrm{N}$-cadherin, which is preferentially expressed in cells with a more mesenchymal phenotype [9]. Cadherin composition fluctuates during tumor progression and metastasis as a response to the different microenvironments. 
Loss of E-cadherin weakens the adherens junctions involved in cell-cell adhesion and facilitates the release of the cells from the primary tumors. $\mathrm{N}$-cadherin was reported to promote aggregation and collective cell migration that facilitates invasion and metastasis [10-12]. Indeed, there exists a vast literature describing the increase of $\mathrm{N}$-cadherin expression in cancer metastasis (see [13] for a recent review).

Despite the increasing number of publications describing the association of other cadherins which are different to $\mathrm{E}$ - and $\mathrm{N}$-cadherin in terms of cancer development and progression, the characterization of these alternative cadherins remains poorly investigated. In this review, we will discuss the structural and functional properties of cadherin 5 (CDH5), cadherin 6 (CDH6) and cadherin 17 (CDH17), as well as their pathological implications in cancer progression and metastasis. These cadherins have, in common, the presence of RGD motifs within their sequence. Although another two cadherins, CDH16 and CDH20, contain RGD motifs, they will not be reviewed here as their relationship with cancer metastasis is not well established. In addition, we will discuss the implication of these three RGD cadherins in cancer signalling pathways and how this signalling might be regulated by the interaction network of each cadherin. Finally, we will address their emerging value as therapeutic targets for the treatment of cancer metastasis.

\section{RGD Cadherins Structure and Function}

\subsection{Cadherin 17}

CDH17 (also known as liver-intestine cadherin or LI-cadherin), together with CDH16, belongs to the 7D cadherin family, characterized by having seven extracellular (EC) domains [14]. CDH17 has been well characterized at the structural level in the last two decades. EC domains 1-2 have originated by a duplication of the first two domains of a 5-repeat cadherin [15]. The conserved tryptophan at position 2 in the EC1 of classical cadherins has been replaced by a phenylalanine in CDH17 [16]. Both 7D cadherins contain an RGD motif, which is located in the EC6 domain in CDH17. Another relevant structural difference in 7D cadherins is the absence of a large cytoplasmic domain when compared to classical or type II cadherins. CDH17 cytoplasmic domain is very short and it has been commonly assumed that it cannot interact with the catenin proteins to bind to the actin cytoskeleton. According to this hypothesis, cell signalling would require cooperation with other molecules. However, our group recently described the association of CDH17 with $\beta$-catenin and p120-catenin using an immunoprecipitation approach [17]. Indeed, the interaction with p120-catenin might use two dileucine motifs (LL) which are present in CDH17 positions 792-793 and 796-797 just at the end of the transmembrane region. The dileucine motif is the core p120-catenin binding site used for E-cadherin endocytosis [18]. We can hypothesize that the interaction with $\beta$-catenin might use some other residues of the short cytoplasmic tail. Alternatively, we cannot discard that the interaction with the $\beta$-catenin occurs indirectly through interactions with other catenins and/or proteins.

EC domains of cadherins are usually cleaved near the plasma membrane by different proteases, including matrix metalloproteinases (MMPs) (MMP3, MMP6, MMP9, MT1-MMP (MMP14) or Disintegrin and Metalloproteinase Domain-Containing Protein 10 (ADAM10)) and kallikrein 6 in the case of E-cadherin [4]. These fragments may block the homotypic binding of cadherins to facilitate cell migration and invasion [19]. A similar shedding has been observed for CDH17 [20], although the protease(s) involved in this shedding have not been characterized yet. These soluble CDH17 fragments might be relevant for "trans" interactions between cadherin subunits or between cadherin-integrin subunits, as we will discuss later.

Regarding phylogenetic analysis, CDH17 is well preserved in all mammalians, even an ancestral $\mathrm{CDH} 17$ gene was identified in zebrafish kidney development that can be considered the precursor of the mammalian genes $C D H 17$ and $C D H 16$ [21]. In physiological conditions, $\mathrm{CDH17}$ is only expressed in the small and large intestine in humans and mice, but not in the upper gastric tract or the liver [22]. In mice, CDH17 expression starts at day 12.5 matching the formation of the intestinal villi and it was always 
co-expressed with E-cadherin in polarized cells [23]. CDH17 is located exclusively on the basolateral membrane of hepatocytes, enterocytes and goblet cells but not on the apical plasma membrane.

$\mathrm{CDH} 17$ is mainly a $\mathrm{Ca}^{2+}$-dependent cell-cell adhesion protein. These cell-cell adhesion properties induce cell clustering at a similar level to classical cadherin [23]. Interaction between CDH17 molecules occur in a trans mode and are preferentially homophilic, although some heterotypic interactions with other cadherins might be possible. Moreover, the homotypic interaction of CDH17 displays higher affinity than the corresponding interactions of classical cadherins. This property of CDH17 might be relevant for the formation of cell micro-aggregates to facilitate the formation of micrometastasis. The homotypic interaction of CDH17 is only possible in cholesterol-rich domains ("lipid rafts") and is dependent of cholesterol levels [24]. The precise biological function of CDH17 is still a matter of debate. CDH17 has been involved in water resorption under various osmotic conditions by adjusting the intercellular cleft [25]. Therefore, $\mathrm{CDH} 17$ would participate in the regulation of water transport through epithelia. Water transport might be related to and/or regulated by the $\mathrm{Ca}^{2+}$ concentration, which is necessary to retain the CDH17-mediated adhesion. It has been published that the removal of $\mathrm{Ca}^{2+}$ increases the diffusion coefficient of the CDH17 in plasma membrane [26], making $\mathrm{Ca}^{2+}$ levels critical for cadherin trans-interactions. This CDH17 ability that combines the clustering of the EC domains in combination with high mobility might facilitate the formation of highly dynamic adhesive contacts. In summary, CDH17 cell-cell-mediated adhesion is highly dependent of $\mathrm{Ca}^{2+}$ concentration, which in turn, depends on the overall electrolyte concentration and the water resorption processes. It is interesting to note that $\mathrm{Ca}^{2+}$ alterations have been considered relevant in the hallmarks of cancer progression [27]. Although there are very few data about the relationship between CDH17 expression and proteins involved in the regulation of $\mathrm{Ca}^{2+}$ levels, it is noteworthy that a number of alterations in these proteins have been routinely observed in colorectal cancer metastasis. These correlations deserve further study.

\subsection{VE-Cadherin}

$\mathrm{CDH} 5$, also known as vascular-endothelial (VE)-cadherin, belongs to the type II cadherin family. As for other members of the family, its structure consists of five EC domains, a single-pass transmembrane domain and the cytoplasmic domain [28]. Cell-cell adhesion is established by homotypic interactions between the five EC domains that are stabilized by binding of $\mathrm{Ca}^{2+}$ ions to the cadherin repeats [29]. Antibodies against domains EC1 and EC4 have demonstrated a role for these regions in cell-cell adhesion and endothelial integrity [30]. RGD motifs are located in EC2 and EC3, which is different from the adhesion motifs. In a similar way to CDH17, VE-cadherin RGD motifs are present in many mammals and birds, but not in rodents or dogs [31]. The cytoplasmic tail of VE-cadherin interacts with p120-catenin, $\beta$-catenin and plakoglobin [32]. These catenins form the structural bridges with the actin cytoskeleton to enhance adhesion. These interactions are variable: in recently formed vessels; cell to cell contacts are less stable and more prone to migration and proliferation. In contrast, mature endothelial cells are more stable in order to maintain vascular structure, inhibiting cellular expansion and migration. The VE-cadherin signaling capacity in endothelial cells has been extensively reviewed (i.e., [32]). Soluble VE-cadherin fragments have been found in the blood of patients with systemic inflammation and sepsis and were involved in the endothelial barrier breakdown [33]. As described for E-cadherin, the shedding of VE-cadherin EC domains involves ADAM10 and appears to be of clinical relevance in cardiovascular diseases. Its role in cancer progression remains to be clarified.

VE-cadherin activity is modulated by phosphorylation of the Tyr residues of the cytoplasmic domain by phosphatases and kinases, which regulate signaling and junctional permeability. Three Tyr residues (Y645, Y658 and Y685) in the cytoplasmic tail are targets of different kinases (i.e., Src or C-terminal Src kinase (Csk)) [34]. Whereas Src-mediated phosphorylation promotes increased permeability, dephosphorylation by protein tyrosine phosphatases induces junctional strength. Phosphorylation of Y645 by Csk may lead to the inactivation of Src activity and, then, that of 
focal adhesion kinase (FAK) at adherens junctions leading to $\beta$-catenin dissociation from VE-cadherin in angiogenesis [35]. The vascular endothelial growth factor (VEGF) family is the main factor for angiogenesis regulation. VEGF may modulate the activity of the p120-catenin and $\beta$-catenin through the VEGFR2 to induce a reduced presence of VE-cadherin in the adherens junctions. Many other signaling events are modulated by VE-cadherin in endothelial cells (for a complete review see [36]). VE-cadherin is selectively expressed at the adherens junctions of the endothelial cells and, therefore, an overwhelming percentage of studies about its function are related with cardiovascular research. VE-cadherin studies in cancer progression and metastasis are much more limited and were mainly restricted to its function in vasculogenic mimicry until recently. New findings in TGF $\beta$ activation and integrin interactions demonstrated new roles for this cadherin in metastatic progression (see Sections 3.2 and 5).

\subsection{Cadherin 6}

$\mathrm{CDH6}$, also known as fetal kidney cadherin or K-cadherin, is involved in the morphogenesis and development of the embryonic kidney, where it drives the mesenchymal-epithelial differentiation that is necessary for kidney morphogenesis [37,38]. However, in the adult kidney, CDH6 expression is very weak or negligible [39,40]. CDH6 is a type II cadherin (like VE-cadherin), which has not been extensively investigated, and is characterized as containing 5 EC domains and a large cytoplasmic domain for the interaction with catenin molecules. CDH6 contains the RGD motif at the EC1 domain and the His-Ala-Val (HAV) motif for stabilization and clustering of adjacent monomers at the EC5. In contrast, human $\mathrm{CDH} 17$ and $\mathrm{CDH} 5$ do not contain HAV motifs. $\beta$-catenin binds directly to the cytoplasmic tail of cadherins and to $\alpha$-catenin to regulate the actin cytoskeleton. Given the central role of $\beta$-catenin in the Wnt signaling pathway, a link between $\beta$-catenin signaling and cell-cell adhesion mediated by CDH6 has been suggested [41]. In Madin-Darby canine kidney (MDCK) cells, loss of $\mathrm{CDH} 6$ in the presence of active $\beta$-catenin led to more flat and less compacted colonies than control cells [41]. Therefore, CDH6-low cells tend to be more spindly, fibroblast-like and more migratory and invasive [42]. This role seems to agree with the promigratory/proinvasive properties of CDH17 low cells. CDH6 is also expressed in platelets, having a functional role in platelet aggregation and thrombus formation. This function is mediated by the binding of the RGD motif to $\alpha \operatorname{IIb} \beta 3$ integrin, which undergoes a conformational change and binds fibrinogen for the cross-linking of platelets [43]. From the very beginning, CDH6 was associated with high expression in renal carcinomas [44,45]. However, beyond its role in morphogenesis, platelets and cancer progression (see Section 3.3), little is known about the biological functions of CDH6.

\section{Relevance of CDH17, CDH5 and CDH6 in Cancer Progression and Metastasis}

\subsection{Cadherin 17 in Gastrointestinal Cancers and Other Tumors}

Despite some initial conflicting results, high CDH17 expression is clearly associated with metastatic progression in different neoplasias, mainly of gastrointestinal origin. Most of the previous conflicting results were due to the unknown association of $\mathrm{CDH} 17$ expression with the differentiation status of the tumor. Whereas well-differentiated tumors express high amounts of CDH17 in late stages, poorly-differentiated tumors do not express CDH17. High expression of CDH17 in cancer cells correlates in general with a high expression of the intestine-specific transcription factor CDX2, which regulates CDH17 expression [45] and plays a key role in the intestinal epithelial development and differentiation [46]. Therefore, some initial studies restricted to aggressive and poorly-differentiated colorectal and pancreatic carcinomas observed negligible amounts of CDH17 and presumed that CDH17 was generally reduced in advanced colorectal and pancreatic cancer. The use of a larger series of samples, including well-differentiated tumors has clarified this issue.

CDH17 is highly expressed in gastric cancer [47,48], pancreatic cancer [49,50], particularly in the exocrine-like subtype of pancreatic ductal adenocarcinoma [51], Barrett's esophagus and associated carcinoma [52], neuroendocrine tumors [53,54], colorectal cancer $[45,50,55,56]$ and hepatocellular 
carcinoma [57-59]. In many of these cancers, CDH17 expression is associated with tumor stage or poor survival of patients [37,38]. Indeed, CDH17 is considered a sensitive marker for the detection of metastasis of unknown primary origin and for their subsequent assignation to the gastrointestinal tract [60]. Regarding other tumors, up-regulation of CDH17 was observed in advanced stages of epithelial ovarian cancer and associated with poor prognosis [61]. CDH17 was also associated with mucinous epithelial ovarian cancer [62]. Indeed, high expression of CDH17 in this subtype of ovarian cancer can be readily observed in the Human Protein Atlas [63]. In addition, CDH17 has been used to distinguish primary adenocarcinomas of the bladder from urothelial carcinoma with glandular differentiation [64]. All these results confirm the increased relevance of CDH17 in the metastatic progression of a wide range of solid tumors.

Regarding gene expression regulation, an analysis of the microRNA (miRNA) expression in the highly metastatic colorectal cancer cell line KM12SM, indicated that three miRNAs (miR-424-3p, -503, and -1292), overexpressed in the metastatic cells, caused an increased expression of CDH17 [65]. This report concluded that multiple miRNAs regulate the expression of the same set of proteins, which might be necessary for more efficient control of the metastatic process. Therefore, CDH17 expression seems to be regulated in a coordinated way by multiple miRNAs. Regarding signaling, CDH17 has been implicated in different signaling pathways. In hepatocarcinoma, loss of CDH17 expression was associated with inactivation of the Wnt signaling pathway and a significant reduction of total and nuclear $\beta$-catenin and the phosphorylated form of Glycogen Synthase Kinase 3 Beta (GSK-3 $\beta$ ) [57] (Figure 1). CDH17 has also been reported to alter MMP9 and MMP2 expression via activation of the NF-kB signaling pathway in gastric cancer $[66,67]$ (Figure 1). In colorectal cancer, we have confirmed the interaction of $\mathrm{CDH} 17$ with $\alpha-, \beta-$, and p120-catenins [17]. In addition, we have observed a large effect of CDH17 on cell adhesion and proliferation in metastatic colorectal cancer cell lines [17]. This impact was mediated by the binding of CDH17 to the $\alpha 2 \beta 1$ integrin and the subsequent activation of the integrin signaling pathway and increased binding to collagen IV [20]. This binding was mediated by an RGD motif present in the CDH17 in humans and other mammalians (see Section 5). Therefore, the RGD motif in cadherins seems to work as a switch that regulates integrin activation in different types of metastatic cells. The observed increase of $\alpha 2$ integrin expression during liver metastasis suggests that the co-expression of CDH17 and the $\alpha 2$ integrin is necessary for the pro-metastatic activity [68].

\subsection{VE-Cadherin in Breast Cancer, Melanoma and Other Tumors}

VE-cadherin overexpression has been reported in a number of neoplasias. In a pioneer work, VE-cadherin was associated with vasculogenic mimicry (the ability of cancer cells to form novel blood-vessel-like structures) in uveal melanoma [69,70]. This capacity was further confirmed in glioblastoma stem-like cells [71] and many other tumors [72]. Vasculogenic mimicry constitutes an alternative way to secure the blood supply to tumors and makes the use of antiangiogenic drugs in cancer more inefficient. Vasculogenic mimicry is a key process in pediatric cancers as astrocytomas [73] and rhabdomyosarcomas [74] and is correlated with poor survival. In other childhood cancers, VE-cadherin is overexpressed in Ewing's sarcoma [75] and is a stem cell marker of Philadelphia positive $(\mathrm{Ph}+)$ cells, including $\mathrm{Ph}+$ acute lymphoblastic leukemia (ALL) and chronic myeloid leukemia blast crisis cells, where CDH5 contributes to cell survival [76]. Expression of VE-cadherin and Platelet and Endothelial Cell Adhesion Molecule 1 (PECAM-1) by ALL cells enhanced adhesion and migration across brain microvascular endothelial cell monolayers [77]. Indeed, VE-cadherin has been suggested as a potential target for the treatment of $\mathrm{Ph}+$ leukemias [78]. VE-cadherin is also overexpressed in lung cancer [79] and highly aggressive cutaneous melanomas [80]. Recently, VE-cadherin has been postulated as a biomarker for metastatic breast cancer [81], particularly in estrogen-receptor-positive breast cancers with vascular invasion, where its expression correlates with metastasis [82]. CDH5 mRNA was also found up-regulated in pancreatic neuroendocrine tumors in sporadic and Von-Hippel Lindau patients [83]. High CDH5 expression correlates with tumor progression, metastasis and poor 
survival in patients with differentiated-type gastric cancer [84]. In esophageal cancer tissues, CDH5 mRNA expression correlated with the expression of VEGF molecules [85]. VEGF expression is higher in differentiated tubular adenocarcinomas than in signet-ring cell carcinoma.

An initial characterization of the VE-cadherin role in cancer cell signaling was made in the mouse mammary epithelial cell line EpH4 transformed by the v-Ha-Ras oncogene, where there was a significant increase of VE-cadherin expression, accompanied by a down-regulation of E-cadherin [86]. This effect was associated with EMT, as treatment with Transforming Growth Factor beta (TGF- $\beta$ ) of the same parental cells caused similar alterations in phenotype and protein expression in the long-term (Figure 1). However, the authors clearly established that VE-cadherin was not a target directly regulated by TGF- $\beta$. Regarding vasculogenic mimicry, CDH5 regulates EPH Receptor A2 (EphA2) expression in melanoma cells [87] and, conversely, CDH5 expression was significantly decreased after knockdown of hypoxia-inducible factors (HIF1 $\alpha$ or HIF2 $\alpha$ ) in glioblastoma [88] (Figure 1). Therefore, hypoxic conditions would induce $\mathrm{CDH} 5$ participation in vasculogenic mimicry. In addition, we reported the interaction of $\mathrm{CDH} 5$ with $\alpha 2 \beta 1$ integrin in melanoma and breast cancer cells to activate the integrin signaling pathway, promoting migration and invasion and, consequently, metastasis in a similar way to CDH17 [31]. In summary, several mechanisms have been proposed to explain the VE-cadherin role in vasculogenic mimicry, cancer progression and metastasis. Further work is necessary to interconnect the different mechanisms and to clarify if they are cell-context specific.

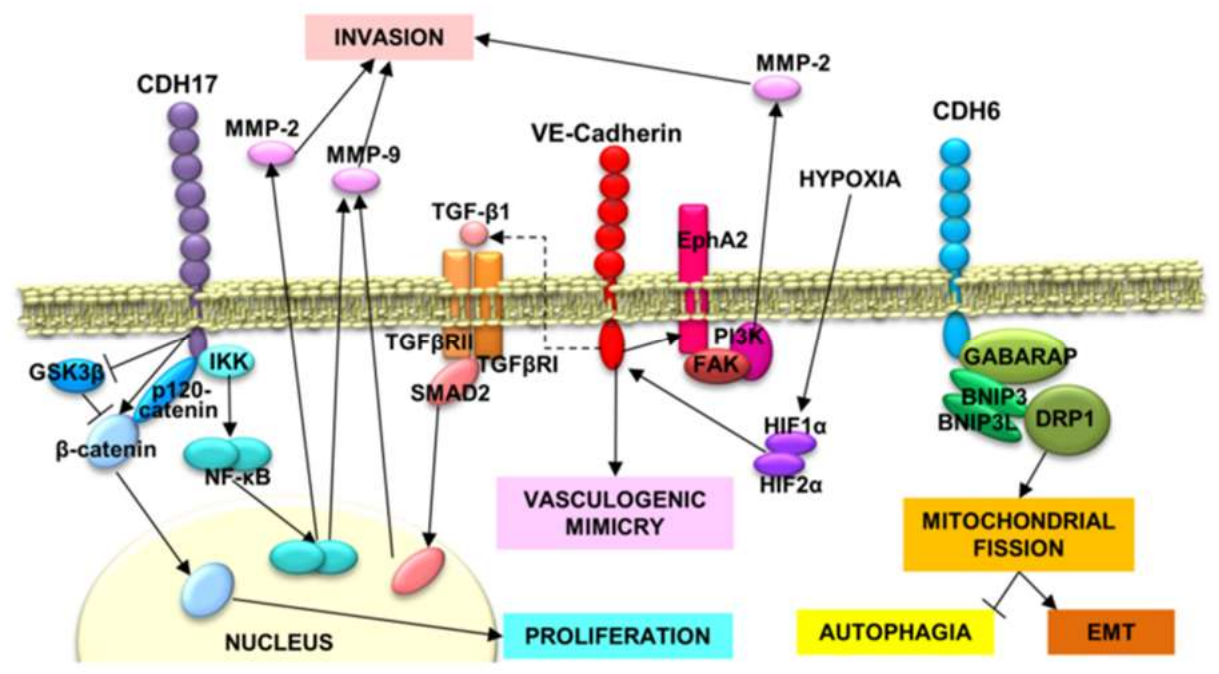

Figure 1. Cancer-related signaling pathways involving RGD cadherins. CDH17-triggered phosphorylation of IкB Kinase (IKK) causes NF- $\kappa$ B release and translocation to the nucleus, where it promotes the expression of MMP-2 and MMP-9, allowing a more efficient cell invasion of the extracellular matrix. In addition, CDH17 downregulates GSK3 $\beta$ activation, promoting the accumulation of $\beta$-catenin and its nuclear translocation to induce the expression of cyclins and other proteins involved in proliferation. Vascular-endothelial (VE)-cadherin expression is modulated by hypoxia-induced factors, HIF1 $\alpha$ and HIF2 $\alpha$. VE-cadherin, in addition to induce vasculogenic mimicry and promotes EphA2 stabilization in cell membrane, which in turn, activates FAK and PI3K. PI3K increases the activation of MMP-2, favoring the invasion. VE-cadherin also induces the expression of TGF- $\beta 1$, which induces Mothers Against Decapentaplegic Homolog 2 (SMAD2) phosphorylation and nuclear translocation to promote MMP-9 expression and, subsequently, cell invasion. CDH6, next to GABARAP, Dynamin-Related protein 1(DRP1), BNIP3 and BINP3L, promote mitochondrial fission through DRP1, which impedes autophagia and promotes the epithelial-mesenchymal transition.

\subsection{Cadherin 6 Expression in Different Tumors}

According to its initial location, $\mathrm{CDH} 6$ was mainly implicated in renal carcinomas, where it correlates with lymph node invasion and metastasis $[43,44,89]$. In addition, $\mathrm{CDH} 6$ expression has been observed in ovarian carcinoma [90,91], thyroid cancers [92,93], cholangiocarcinoma [94], hepatocellular and small-cell lung carcinoma [39]. Regarding pediatric cancers, CDH6 overexpression was observed in osteosarcoma and 
was associated with the overall survival and prognosis of osteosarcoma patients [95], where CDH6 expression was regulated by miR-223-3p. CDH6 seems to be strongly expressed in aggressive thyroid carcinomas [96] and nasopharyngeal carcinoma [97]. In addition, RNA-seq data and tissue immunohistochemistry confirmed the restricted normal tissue distribution of $\mathrm{CDH} 6$ and the preferential expression in renal and ovarian cancers [98]. To note that $\mathrm{CDH} 6$ overexpression seems to be related to cancers originating from developmentally related mullerian, renal and thyroid lineages. Transcription factor Paired Box 8 (PAX8), common to these three lineages, seems to regulate the expression of $\mathrm{CDH} 6$ [99]. Interestingly, in some ovarian cancers, overexpression of $\mathrm{CDH} 17$ has been reported, suggesting that both cadherins might coexist in some cancer tissues. A recent report has investigated the association of cadherins, including CDH6 and CDH17, with stem-cell-related transcription factors in triple negative breast cancer (TNBC) [100]. There was a significant percentage of TNBC samples from TCGA datasets with alterations in CDH17 (20\%) and CDH6 (14\%). In addition, a clear concurrence of stem-cell-related transcription factors (Forkhead Box M1 (FOXM1), SNAI1, SRY Box 9 (SOX9), Minichromosome Maintenance Complex Component 2 (MCM2), among others) expression with alterations in $\mathrm{CDH} 6$ and $\mathrm{CDH} 17$ was observed. The authors propose that the loss of E-cadherin is compensated by the upregulation of several other cadherins, including CDH6 and CDH17, as well as an increased expression of transcription factors such as Snail, SOX9 or FOXM1.

Regarding signaling, CDH6 was described as a TGF- $\beta$ target gene in thyroid cancer cell lines to promote a mesenchymal phenotype [101]. However, these results were conflicting with the functional role of $\mathrm{CDH} 6$ in epithelial morphogenesis. Furthermore, the transcription factor RUNX2 was proposed to be involved in the regulation of $\mathrm{CDH} 6$ in these cell lines [101], conflicting with the reports of PAX8 implication. In addition, CDH6 was reported to interact with autophagy-related proteins GABA Type A Receptor-Associated Protein (GABARAP), BCL2 Interacting Protein 3 (BNIP3) and BNIP3L to restrict autophagy and to promote the reorganization of the mitochondrial network in thyroid cancer cells [102] (Figure 1). The interaction with the autophagic proteins is mediated by short motifs called LC3-interacting (LIR) domains. These LIR domains seem to be present in other cadherins such as VE-cadherin, but not in the 7D cadherins (CDH17 and CDH16), probably due to the short cytoplasmic domain. Although we might assume a relationship between cadherin re-expression in advanced neoplasias as being related to epithelial plasticity and reacquisition of a more epithelial phenotype, the link between EMT and autophagy is unclear. It has been described that autophagy improves viability and survival by increasing anoikis resistance and immune surveillance escape.

\section{Phylogenetic Analysis of the RGD Motif in Cadherins}

Phylogenetic analysis of cadherin sequences reveals the evolutionary history of the RGD motif in cadherins. The RGD motif in CDH6 appears very early in evolution, as most fish (80\% of analyzed sequences) have this motif around position 86 in the $\mathrm{CDH} 6$ amino acid sequence. This motif is highly conserved in mammals, fishes and turtles (Figure 2, Figure 3). However, the diapsida (lizards, crocodiles and birds) present a mutation that changes the RGD motif into a KGD motif (Figure 3). In contrast, RGD motifs in CDH17 and VE-Cadherin are more recent in evolution. The RGD motif in CDH17 is exclusively present in placental mammals (57\%, position 603) (Figure 2). To note the lack of RGD motif in the CDH17 sequence of carnivores, rodents (mouse, rats) and lagomorphs (rabbits). Something similar happens for the VE-cadherin RGD motifs, whereas RGD in VE-cadherin sequence is found in placental mammals (43\%) and birds (64\%) with similar exceptions [31]. However, the position of the RGD motif in VE-cadherin shows a parallel development, as it is present in cadherin EC domain 2 in mammals but in domain 3 in birds. In fact, the RGD motif in VE-cadherin has appeared several times in evolution, as placental mammals show this motif in different positions: 83, 191 and 236 in the amino acid sequence. In addition, primates show a second RGD motif in position 299 (in the cadherin domain 3) [31]. 


\begin{tabular}{|c|c|c|c|c|c|}
\hline $\begin{array}{l}\text { COMMON } \\
\text { NAME }\end{array}$ & UPPER CLADE & SUPERORDER & ORDER & SPECIES & CDH6 RGD \\
\hline \multirow{9}{*}{$\begin{array}{l}\text { Ray-finned } \\
\text { fishes }\end{array}$} & \multirow{9}{*}{ Teleostei } & \multirow{2}{*}{ Ostariophysi } & \multirow{2}{*}{ Cypriniformes } & Cyprinus carpio & 78 \\
\hline & & & & Danio rerio & 78 \\
\hline & & \multirow{7}{*}{ Acanthopterygii } & Cyprinodontiformes & Aphyosemion striatum & KGD 77 \\
\hline & & & Cyprinodontiformes & Nothobranchius furzeri & KGD 76 \\
\hline & & & & Labrus bergylta & 86 \\
\hline & & & Perciformes & Parambassis ranga & 86 \\
\hline & & & & Seriola dumerili & 85 \\
\hline & & & Beloniformes & Oryzias latipes & 86 \\
\hline & & & Anabaniformes & Anabas testudineus & 86 \\
\hline \multirow{4}{*}{ Turtles } & \multirow{4}{*}{ Pantestudines } & \multirow{4}{*}{ Testudinata } & \multirow{4}{*}{ Testudines } & Chelonia mydas & 84 \\
\hline & & & & Chrysemys picta & 84 \\
\hline & & & & Pelodiscus sinensis & 84 \\
\hline & & & & Terrapene mexicana & 84 \\
\hline \multirow{4}{*}{$\begin{array}{l}\text { Lizards ans } \\
\text { snakes }\end{array}$} & \multirow{4}{*}{ Lepidosauromorpha } & \multirow{4}{*}{ Lepidosauria } & \multirow{4}{*}{ Squamata } & Anolis carolinensis & KGD 83 \\
\hline & & & & Pogona vitticeps & KGD 84 \\
\hline & & & & Podarcis muralis & KGD 83 \\
\hline & & & & Protobothrops mucrosquamatus & KGD 84 \\
\hline Crocodiles & \multirow{6}{*}{ Palaeognathae } & Crocodylomorpha & Crocodilia & Alligator sinensis & KGD 83 \\
\hline \multirow{43}{*}{ Birds } & & Struthionimophae & Struthioformes & Struthio camelus & KGD 83 \\
\hline & & & Casuariformes & Dromaius novahollandiae & KGD 83 \\
\hline & & & Apteryformes & Apteryx australis & KGD 83 \\
\hline & & Notopalaeognathae & & Nothoprocta perdicaria & KGD 83 \\
\hline & & & Tinamiformes & Tinamus guttatus & KGD 83 \\
\hline & & & Galliformes & Meleagris gallopavo & KGD 83 \\
\hline & & & Anseriformes & Anser cygnoides & KGD 83 \\
\hline & & Galloanserae & Columbiformes & Columba livia & KGD 83 \\
\hline & & & Cuculiformes & Cuculus canorus & KGD 84 \\
\hline & & & Anodiformes & Calypte anna & KGD 84 \\
\hline & & & Apodiformes & Chaetura pelagica & KGD 84 \\
\hline & & & Opisthocomiformes & Ophistocomus hoazin & KGD 83 \\
\hline & & & Charadriiformes & Calidris pugnax & KGD 83 \\
\hline & & & & Charadrius vociferus & KGD 83 \\
\hline & & & Gaviiformes & Gavia stellata & - \\
\hline & & & & Anas platyrhynchos & KGD 83 \\
\hline & & & Sphenisciformes & Aptenodyter forsteri & KGD 83 \\
\hline & & & & Pygoscelis adeliae & KGD 83 \\
\hline & & & & Egretta garzetta & KGD 83 \\
\hline & & & & Nipponia nippon & KGD 83 \\
\hline & & & Pelecaniformes & Pelecanus crispus & KGD 7 \\
\hline & & & & Pheethon lepturus & KGD 83 \\
\hline & & & & Phalacrocorax carbo & KGD 84 \\
\hline & Neognathae & & Accipitriformes & Aquila chrysaetos & KGD 83 \\
\hline & & & Accipitritormes & Haliaeetus leucocephalus & KGD 83 \\
\hline & & & Strigiformes & Athene cunicularia & KGD 83 \\
\hline & & Neoaves & Coliiformes & Colius striatus & KGD 83 \\
\hline & & & Trogoniformes & Apaloderma vittatum & KGD 83 \\
\hline & & & Bucerotiformes & Buceros minoceros & KGD 83 \\
\hline & & & Piciformes & Picoides pubescens & KGD 84 \\
\hline & & & Cariamiformes & Cariama cristata & KGD 83 \\
\hline & & & Falconiformes & Falco cherrug & KGD 84 \\
\hline & & & & Gallus gallus & KGD 84 \\
\hline & & & Psittaciformes & Melopsittacus undulatus & KGD 84 \\
\hline & & & & Nestor notabilis & KGD 84 \\
\hline & & & & Acanthisitta chloris & KGD 83 \\
\hline & & & & Cyanistes caeruleus & KGD 83 \\
\hline & & & & Epidonax traillii & KGD 84 \\
\hline & & & Passeriformes & Ficedula albicollis & KGD 83 \\
\hline & & & & Geospiza fortis & KGD 83 \\
\hline & & & & Manacus vitellinus & KGD 84 \\
\hline & & & & Pseudopodoces humilis & KGD 83 \\
\hline & & & & Stumus vulgaris & KGD 83 \\
\hline
\end{tabular}

Figure 2. Phylogenetic analysis of the RGD motif in CDH6. Classification of vertebrates (excluding mammals) where the CDH6 gene has been sequenced, indicating the position of the RGD or KGD motif in the sequence.

The physiological role of RGD motifs in cadherins has been studied only in CDH6. This RGD cadherin is expressed in platelets and plays a key role in coagulation through the activation of $\alpha \mathrm{Ilb} \beta 3$ integrin [103]. Such an important function might explain the early origin of this motif. The KGD mutation found in many reptiles and birds probably has no deleterious effect, as this motif is likely recognized by $\alpha \mathrm{Ilb} \beta 3$ integrin [104,105]. The role of RGD motifs in other cadherins has not been studied in physiological conditions. However, since CDH17 promotes cell adhesion and proliferation through activation of $\alpha 2 \beta 1$ integrin [20], we tentatively propose that the CDH17 RGD motif can promote enterocyte cell-cell adhesion and, particularly, cell proliferation. In fact, intestinal epithelium is the human tissue with the highest proliferation and replacement rate. Regarding the VE-cadherin RGD motif, this cadherin promotes cell adhesion and proliferation, but also increases their migratory/invasive behavior in tumor cells. VE-cadherin is mainly expressed in endothelial cells, where its RGD motif could promote cell migration through activation of $\alpha 2 \beta 1$ integrin. The $\alpha 2 \beta 1$-triggered migration of endothelial cells is known to be of key relevance in angiogenesis [106]. Therefore, VE-cadherin RGD motif may promote angiogenesis and vascular development in homeotherm animals (mammals and birds). 


\begin{tabular}{|c|c|c|c|c|c|}
\hline UPPER CLADE & SUPERORDER & ORDER & SPECIES & CDH6 RGD & CDH17 RGD \\
\hline \multirow{2}{*}{ Marsupalia } & Ameridelphia & Didelphimorpha & Monodelphis domestica & 83 & - \\
\hline & Austrlidelphia & Dasyuromorpha & Sarcophilus harrisi & $?$ & - \\
\hline \multirow{59}{*}{ Placentalia } & \multirow{5}{*}{ Afrotheria } & \multirow{2}{*}{ Afrosoricida } & Chrysochloris asiatica & 83 & - \\
\hline & & & Echinops telfari & 83 & - \\
\hline & & Tubulidentata & Orycteropus afer & 83 & - \\
\hline & & Proboscidea & Loxodonta africana & $?$ & - \\
\hline & & Sirenia & Trichechus manatus & 83 & - \\
\hline & Xenarthra & Cingulata & Dasypus novemcinctus & $?$ & 601 \\
\hline & \multirow{25}{*}{ Euarchontoglires } & Scandentia & Tupaia chinensis & 83 & 607 \\
\hline & & Dermoptera & Galeopterus variegatus & - & - \\
\hline & & \multirow{12}{*}{ Primates } & Otolemur gamettii & ? & 603 \\
\hline & & & Callithrix jacchus & 83 & 603 \\
\hline & & & Saimir boliviensis & - & 603 \\
\hline & & & Papio anubis & 83 & - \\
\hline & & & Chlorecebus sabaeus & 83 & 603 \\
\hline & & & Macaca mulatta & 83 & 603 \\
\hline & & & Nomascus leucogenys & 83 & 603 \\
\hline & & & Pongo abelii & 83 & 603 \\
\hline & & & Gorilla gorilla & 83 & - \\
\hline & & & Pan paniscus & 82 & 603 \\
\hline & & & Pan troglodytes & 83 & 603 \\
\hline & & & Homo sapiens & 83 & 603 \\
\hline & & \multirow{2}{*}{ Lagomorpha } & Ochotona princeps & 83 & - \\
\hline & & & Oryctolagus cuniculus & 83 & - \\
\hline & & \multirow{9}{*}{ Rodentia } & Mus musculus & 83 & - \\
\hline & & & Cricetulus griseus & 83 & - \\
\hline & & & Peromyscus maniculatus & 82 & - \\
\hline & & & Rattus norvegicus & 82 & - \\
\hline & & & Chinchilla lanigera & 83 & 602 \\
\hline & & & Ictidomys tridecemlineatus & 82 & - \\
\hline & & & Microtus ochrogaster & 83 & - \\
\hline & & & Cavia porcellus & 83 & - \\
\hline & & & Jaculus jaculus & 83 & 602 \\
\hline & \multirow{28}{*}{ Laurasiatheria } & \multirow{3}{*}{ Eulipotyphla } & Erinaceus europaeus & - & - \\
\hline & & & Condylura cristata & 83 & - \\
\hline & & & Sorex araneus & 83 & - \\
\hline & & \multirow{9}{*}{ Artiodactyla } & Sus scrofa & 83 & 603 \\
\hline & & & Bubalus bubalis & 82 & 603 \\
\hline & & & Bos taurus & 83 & 603 \\
\hline & & & Bison Bison & 83 & 603 \\
\hline & & & Vicugna pacos & 82 & 603 \\
\hline & & & Camelus ferus & 83 & 603 \\
\hline & & & Pantholops hodgsonii & 82 & 603 \\
\hline & & & Capra hircus & 83 & 603 \\
\hline & & & Ovis aries & 83 & 603 \\
\hline & & \multirow{5}{*}{ Cetacea } & Lipotes vexillifer & 83 & 591 \\
\hline & & & Delphinapterus leucas & 83 & 603 \\
\hline & & & Tursiops truncatus & 83 & 680 \\
\hline & & & Balaenoptera acutorostrata & 83 & 603 \\
\hline & & & Orcinus orca & 83 & 601 \\
\hline & & \multirow{2}{*}{ Chiroptera } & Pteropus alecto & 83 & 603 \\
\hline & & & Myotis brandtii & KGD 82 & 603 \\
\hline & & \multirow{2}{*}{ Perissodactyla } & Equus caballus & 83 & 601 \\
\hline & & & Ceratotherium simum & 83 & 601 \\
\hline & & Pholidota & Manis javanica & 83 & 603 \\
\hline & & \multirow{6}{*}{ Carnivora } & Panthera tigris & 83 & - \\
\hline & & & Felis catus & 82 & - \\
\hline & & & Canis lupus & 83 & - \\
\hline & & & Mustela putorius & 27 & - \\
\hline & & & Odobenus rosmarus & 83 & - \\
\hline & & & Ailuropoda melanoleuca & 83 & - \\
\hline
\end{tabular}

Figure 3. Phylogenetic analysis of the RGD motif in CDH6 and CDH17 in mammals. Classification of mammal species where CDH17 and/or CDH6 have been sequenced, showing the position of the RGD motifs in such cadherins.

\section{Cadherin Interaction with Integrins: Activation of the Integrin Signaling Pathway by Cadherin RGD Motifs}

Integrins are heterodimeric receptors formed by different combinations of $18 \alpha$ subunits and $8 \beta$ subunits in mammalians [107]. Integrin bi-directional signaling plays a key role in multiple cellular functions including proliferation, adhesion, migration and invasion [107]. The integrin repertoire fluctuates widely between different cell lines impacting cancer development and progression. In general, these alterations are poorly characterized in solid tumors due to the large number of potential integrin heterodimers. Initially, metastasis-associated integrins were mainly limited to the canonical RGD receptor integrins, such as $\alpha \mathrm{v} \beta 3, \alpha \mathrm{v} \beta 5, \alpha 4 \beta 1$ and $\alpha 5 \beta 1$ (see $[108,109]$ for reviews). They were preferentially associated with cancer metastasis, angiogenesis and therapy rather than $\alpha 2 \beta 1$ integrin. Only recently, $\alpha 2 \beta 1$ integrin has received more attention in metastasis research due to the accumulation of evidence that supports a critical role for this integrin in cancer metastasis, including its capacity to bind RGD-containing ligands (see [110] for a review). 
In general, the studies of the interplay between cadherins and integrins have been limited to E-cadherin and N-cadherin. A summary of the interactions between E-cadherin and N-cadherin with different integrins was published by Weber et al. [111]. However, interactions of E-cadherin with different integrins always occurs in an indirect way, forming ternary complexes with other proteins such as insulin-like growth factor 1 receptor [112] or Cell Division Cycle 42 (CDC42) [113]. No direct binding motifs to integrins have been described for E- or N-cadherin to the best of our knowledge. The first direct binding motif to integrins found in cadherins was reported for $\mathrm{CDH} 17$ binding to $\alpha 2 \beta 1$ integrin through the RGD motif in metastatic colorectal cancer cells [20]. Then, we described the interaction of CDH17 and VE-cadherin with $\alpha 2 \beta 1$ integrin in different cellular contexts and cancer models (Figure 4) [17,20,31]. This interaction was facilitated and promoted by the presence of one or two RGD motifs in CDH17 and $\mathrm{CDH} 5$, respectively [20,31]. At the same time, Siret et al. [114] described the association of $\alpha 2 \beta 1$ integrin with both E-cadherin and N-cadherin to regulate melanoma cell invasion. Both cadherins led to different patterns of co-localization and functional activity. Whereas the interaction with $\mathrm{N}$-cadherin promoted invasion and migration towards type I collagen, interaction with E-cadherin promoted cell-cell adhesion, suggesting differential cell responses according to the associated cadherin. However, no other cadherins were investigated in this report. It is unclear how the interaction between $\mathrm{E}$ - and $\mathrm{N}$-cadherin and $\alpha 2 \beta 1$ integrin and other integrins takes place as no RGD motifs are present in these two cadherins. It might be possible that heterophylic interactions between different cadherins are formed or multiple cadherins coexist in the same cells. It seems evident that future interaction studies between cadherins and integrins should not be restricted to the E- and $\mathrm{N}$-cadherins. In any case, interactions between cadherins and integrins have been widely observed and they can modulate a large range of cellular functions, including cytoskeletal organization, cell polarity, cell proliferation and cell adhesion [111]. Therefore, it is critical to understand the molecular mechanisms that drive this interaction and to clarify if there are other molecular motifs involved beyond the RGD motif.

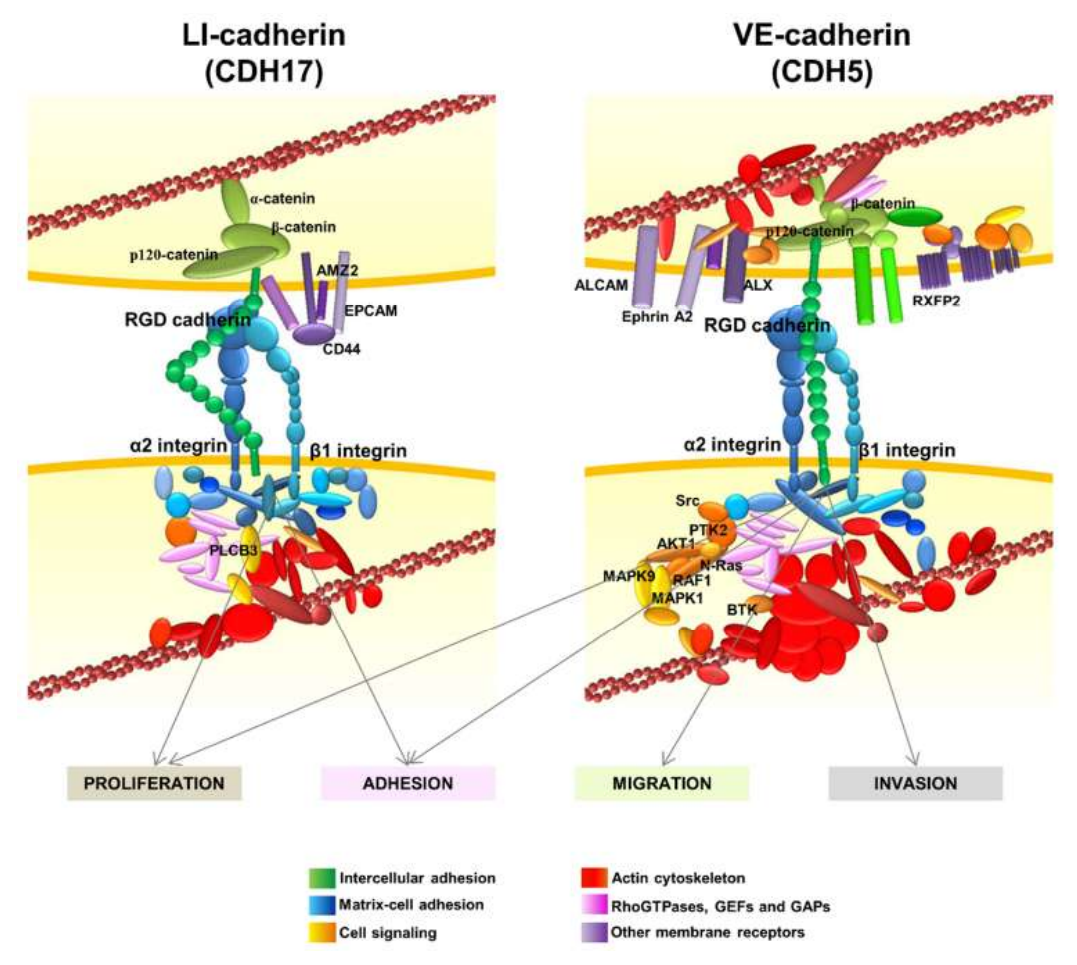

Figure 4. RGD cadherin interactome and integrin signaling in cancer cells. Diagram showing the proteins that specifically bind to CDH17 (left) or VE-cadherin (right) by proteomic analysis and data mining. The most relevant proteins are indicated. Interaction with the RGD cadherins leads to the activation of $\alpha 2 \beta 1$ integrin signaling, which promotes proliferation and adhesion in cancer cells, and also migration and invasion in breast cancer and melanoma cells expressing VE-cadherin. Adapted from [17,31]. 


\section{Other Interactions of RGD Cadherins Involved in Cell Signaling}

In addition to the $\alpha 2 \beta 1$ integrin, the interactome network of $\mathrm{CDH} 17$ revealed several other protein clusters (Figure 4) [17]. Many proteins from the actin cytoskeleton including the main regulators of actin polymerization, the RhoGTPases and their regulators, were identified. Another group of proteins associated with CD44, such as epithelial cell adhesion molecule (EPCAM), galectin 3 (Gal3) and Archaelysin Family Metallopeptidase 2 (AMZ2), were identified in the CDH17 network. This is relevant as CD44 and EPCAM are markers associated with stemness and differentiation. Galectin 3, which was found to cluster with CDH17 in pancreatic ductal adenocarcinoma [49], is involved in the canonical Wnt/ $\beta$-catenin signaling pathway and in the accumulation of nuclear $\beta$-catenin in colorectal cancer [115]. This effect would agree with the reported activation of Wnt signaling when CDH17 is up-regulated in hepatocellular carcinoma [57]. Laminin-interacting $\alpha 6 \beta 4$ integrin was also present in the CDH17 network, although a direct interaction was not demonstrated and no role for $\alpha 6 \beta 4$ integrin in the pro-metastatic proteins of $\mathrm{CDH} 17$ was detected. Thrombospondin 2 and sindecan 1 were also identified as partners of the CDH17 complex as well as $\alpha-, \beta-$, and p120-catenins, suggesting that $\mathrm{CDH} 17$ can bind these proteins even with a short cytoplasmic tail, without homology to those of classical cadherins.

The interactome of VE-cadherin was quite similar to the CDH17 network, including matrix-cell adhesion proteins, actin cytoskeleton and Rho-GTPase associated proteins (Figure 4). As expected, catenins and other cell-cell adhesion proteins were also identified. Despite the overall functional similarity between protein clusters in CDH17 and VE-Cadherin networks; the exact correspondence between proteins was low between both interactomes, probably due to the different cell context in which the cadherins were expressed: CDH17 in colorectal cancer and VE-cadherin in melanoma and breast cancer. Several membrane receptors were identified as part of the VE-cadherin network such as activated leukocyte cell adhesion molecule (ALCAM), ALX homeobox 1 (ALX), EPHA2 and G-protein coupled receptors. High ALCAM expression at the protein level usually correlates with a poor prognosis in melanoma, breast and colorectal cancer, among others [116]. ALCAM expression correlates with melanoma progression, as it is much more abundant in late stages [117]. Note the presence of EPHA2 that was regulated by CDH5 for vasculogenic mimicry in melanoma cells [87]. However, the main difference with CDH17 clusters was the identification in VE-cadherin network of many signaling proteins such as Src kinases, Ras, Phosphoinositide-3-Kinase (PI3K) and Mitogen-Activated Protein Kinase (MAPK) pathway proteins and several phosphatases. Therefore, whereas CDH17 triggers the activation of MAP kinases and Focal Adhesion Kinase (FAK), VE-cadherin can activate Src and PI3K pathways in addition to MAP kinases. These results might explain the different effects of both RGD cadherins in the context of cancer cells: whereas CDH17 promotes cell adhesion and proliferation, VE-cadherin increases cell migration and invasion in addition to adhesion and proliferation [20,31]. The association with other important epithelial/stemnicity markers, such as CD44 and EPCAM with CDH17, and ALCAM and AXL with VE-cadherin, remains to be studied in depth. Potential modulation of functions of these proteins by RGD cadherins could be of key importance in cancer progression. The network of CDH6 remains to be studied in detail.

\section{Targeting Cadherins: Implications in Therapy}

An overview of the reported participation of RGD cadherins in cancer progression and metastasis indicate a wide number of cancer types and subtypes as indicated in the previous sections. This list is probably not exhaustive and is likely to expand in the next years, making these cadherins interesting targets for therapy.

Since E-cadherin expression declines during metastatic progression, it has not typically been considered as a direct therapeutic objective but used as an indirect target for epigenetic regulation. Alternatively, since $\mathrm{N}$-cadherin has been implicated in cancer metastasis endowing tumor cells with enhanced migratory and invasive capacity, a variety of $\mathrm{N}$-cadherin antagonists have been developed and tested. A monoclonal antibody called GC-4, which binds to the EC1 domain of N-cadherin is able 
to block N-cadherin-mediated adhesion and might be relevant to limit metastatic dissemination [13]. GC-4 blocking ability also increased tumor cell sensitivity to imatinib, to overcome tyrosine kinase inhibitor resistance [118]. Another additional therapeutic strategy made use of a stable cyclic peptide called ADH-1 that harbors a HAV motif used for lateral clustering of cadherins [119]. As Fibroblast Growth Factor Receptor 1 (FGFR1) contains a HAV motif, it was assumed that these peptides might also inhibit FGFR signaling. The efficacy of this peptide has been demonstrated in a number of models of pancreatic, breast, colon, ovarian and lung cancer (see [120] for a review). Its efficacy remains to be demonstrated in clinical studies.

The interaction of CDH17 and other cadherins with $\alpha 2 \beta 1$ integrin mediated by an RGD motif enables the development of new therapeutic opportunities based on the inhibition of the cadherin RGD binding. Peptides containing the cadherin RGD motif were used to prepare specific monoclonal antibodies. These monoclonal antibodies blocked the cadherin-mediated $\beta 1$ integrin activation in colorectal, pancreatic, breast and melanoma cancer cell lines [121] (Figure 5). Therefore, the monoclonal antibodies, particularly antibody 6.6.1, blocked the integrin signaling pathway activation of FAK in colorectal cancer, of JNK and ERK kinases, in colorectal and pancreatic cancers, and of JNK, ERK, Src and AKT in melanoma and breast cancers (Figures 4 and 5). These RGD-specific monoclonal antibodies were highly effective in prolonging mice survival in mouse models of liver metastasis (colorectal cancer and melanoma) and lung metastasis (melanoma). Humanized versions of 6.6.1 are being prepared for preclinical studies (unpublished data). Once the effectiveness of these cadherin RGD-specific monoclonal antibodies in cancer models overexpressing CDH17 and VE-cadherin has been demonstrated, the next step should be to investigate the efficacy of these antibodies in other cancers positive for high CDH6 expression, such as ovarian, renal or thyroid cancers.

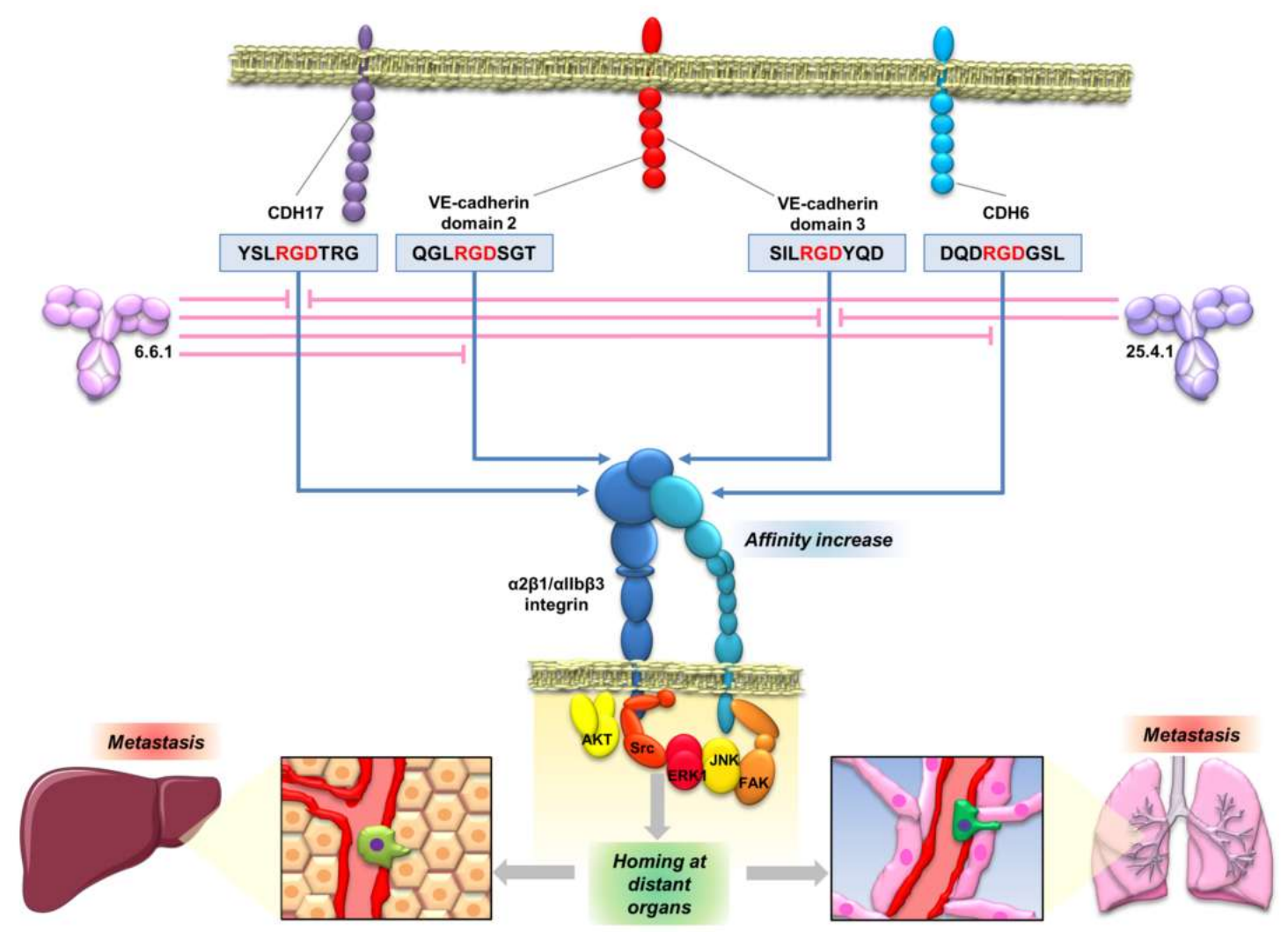

Figure 5. Anti-cadherin RGD antibodies as a potential therapeutic strategy against metastasis. Schematic representation of the activity of two anti-cadherin RGD monoclonal antibodies, showing their specificities against RGD motifs in cadherins. The antibodies can inhibit the interaction of the RGD motifs with the integrins, blocking their activation, signaling and consequently, the metastatic behavior of cancer cells. 
CDH6 has also been identified as a target for biotherapeutics development. The recent discovery and optimization of an antibody-drug conjugate (ADC) directed against this protein has yielded effective results and provided beneficial effects in the treatment of ovarian and renal carcinomas [98]. However, these antibodies used for CDH6 ADC-targeted treatment were not RGD-specific. They bound to a conformational epitope situated in the EC5 domain, working as carriers to vectorise the drug to the cancer cells. Indeed, a naked version of this antibody lacked antitumor efficacy [98].

Targeting of cadherins for cancer treatment raises some questions about the potential complications of targeting proteins with multiple relevant physiological roles. In this regard, although GC-4 antibody or ADH-1 peptide affect the N-cadherin-mediated cell adhesion, ADH-1 seems to be well tolerated in humans [122]. Regarding the anti-cadherin RGD monoclonal antibodies, they have no effect on the main cadherin function: the homotypic cell-cell adhesion, as it is RGD-independent [20]. Moreover, the treatment should affect only cells that simultaneously express RGD cadherins together with $\alpha 2 \beta 1$ or $\alpha \mathrm{IIb} \beta 3$ integrins. Indeed, mouse models where 6.6.1 antibody was used as a treatment for metastasis did not show any side effects [121]. It is noteworthy that the expression levels of cadherins are quite lower in healthy tissues compared with several tumors, where such cadherins are prominently overexpressed or "de novo" expressed, suggesting that most of the targeting will occur in cancer cells. However, it remains to be demonstrated in further clinical trials.

\section{Final Remarks and Outlook}

The three cadherins discussed here share some common features, such as the presence of RGD motifs in the extracellular domains. This RGD motif in CDH17 and VE-cadherin enables the activation of $\alpha 2 \beta 1$ integrin in different cancers and the activation of $\alpha \mathrm{IIb} \beta 3$ integrin in CDH6-expressing tumors (manuscript in preparation). In addition, they are usually re-expressed in advanced metastatic stages of cancer associated to a more epithelial phenotype. They are usually associated with cellular plasticity, including the mesenchymal-to-epithelial transition (MET) and the gain of stem-cell-like properties in metastatic cells, as revealed by the increased expression of CD44, EPCAM and ALCAM, among other markers. The upregulation in late-stage tumors in association with key integrins promotes different pro-metastatic properties in different cancers that support the use of these cadherins as therapeutic targets.

Still, some critical questions remain to be answered such as the potential correlation between the expression of $\mathrm{N}$-cadherin and the RGD cadherins. The potential interaction between $\mathrm{N}$-cadherin and other cadherins has never been explored to the best of our knowledge. The simultaneous co-expression of several cadherins and potential synergies in some tumors deserves further exploration. The involvement of other integrins, such as $\alpha \mathrm{IIb} \beta 3$, in the pro-metastatic mechanisms of CDH6 is currently the subject of research. The presence of soluble fragments of CDH17 and VE-cadherin released by cancer cells may facilitate the signaling capacity with integrins and the formation of trans-interactions between cadherins. Soluble fragments may compete with homotypic interactions to reduce the intercellular adhesion. The proteases involved in this shedding still need to be identified for CDH17. It is also unclear if CDH6 ectodomains are released as soluble fragments to participate in cell signaling. The different position of the RGD motifs in different extracellular domains might be related with a different signaling capacity. Undoubtedly, further exploration of $\mathrm{N}$-cadherin and RGD cadherins' role in cancer metastasis promotion is needed to develop new and more efficient therapeutic strategies.

Acknowledgments: This research was supported by grants BIO2015-66489-R, RTI2018-095055-B-100 and RTC-2017-6260-1 from the MCIU (Spain), PRB3 (IPT17/0019-ISCIII-SGEFI/ERDF) and the Foundation Ramón Areces.

Conflicts of Interest: Rubén A. Bartolomé and J. Ignacio Casal are inventors of a related patent application held/submitted by the Spanish National Research Council. J. Ignacio Casal has stock ownership at Protein Alternatives SL. 


\section{References}

1. Harjes, U. E-selectin fills two needs for metastasis. Nat. Rev. Cancer 2019, 19, 301. [CrossRef] [PubMed]

2. Obenauf, A.C.; Massague, J. Surviving at a distance: Organ specific metastasis. Trends Cancer 2015, 1, 76-91. [CrossRef]

3. Valastyan, S.; Weinberg, R.A. Tumor metastasis: Molecular insights and evolving paradigms. Cell 2011, 147, 275-292. [CrossRef] [PubMed]

4. Berx, G.; van Roy, F. Involvement of members of the cadherin superfamily in cancer. Cold Spring Harb Perspect Biol. 2009, 1, a003129. [CrossRef] [PubMed]

5. Nelson, W.J.; Nusse, R. Convergence of Wnt, beta-catenin, and cadherin pathways. Science 2004, 303, 1483-1487. [CrossRef] [PubMed]

6. van Roy, F.; Berx, G. The cell-cell adhesion molecule E-cadherin. Cell Mol. Life Sci. 2008, 65, 3756-3788. [CrossRef] [PubMed]

7. Soncin, F.; Ward, C.M. The function of e-cadherin in stem cell pluripotency and self-renewal. Genes 2011, 2, 229-259. [CrossRef]

8. Batlle, E.; Sancho, E.; Franci, C.; Dominguez, D.; Monfar, M.; Baulida, J.; Garcia De Herreros, A. The transcription factor snail is a repressor of E-cadherin gene expression in epithelial tumour cells. Nat. Cell Biol. 2000, 2, 84-89. [CrossRef]

9. Wheelock, M.J.; Shintani, Y.; Maeda, M.; Fukumoto, Y.; Johnson, K.R. Cadherin switching. J. Cell Sci. 2008, 121, 727-735. [CrossRef]

10. Hazan, R.B.; Qiao, R.; Keren, R.; Badano, I.; Suyama, K. Cadherin switch in tumor progression. Ann. N. Y. Acad. Sci. 2004, 1014, 155-163. [CrossRef]

11. Shintani, Y.; Hollingsworth, M.A.; Wheelock, M.J.; Johnson, K.R. Collagen I promotes metastasis in pancreatic cancer by activating c-Jun $\mathrm{NH}(2)$-terminal kinase 1 and up-regulating $\mathrm{N}$-cadherin expression. Cancer Res. 2006, 66, 11745-11753. [CrossRef] [PubMed]

12. Klymenko, Y.; Kim, O.; Loughran, E.; Yang, J.; Lombard, R.; Alber, M.; Stack, M.S. Cadherin composition and multicellular aggregate invasion in organotypic models of epithelial ovarian cancer intraperitoneal metastasis. Oncogene 2017, 36, 5840-5851. [CrossRef] [PubMed]

13. Mrozik, K.M.; Blaschuk, O.W.; Cheong, C.M.; Zannettino, A.C.W.; Vandyke, K. N-cadherin in cancer metastasis, its emerging role in haematological malignancies and potential as a therapeutic target in cancer. BMC Cancer 2018, 18, 939. [CrossRef] [PubMed]

14. Berndorff, D.; Gessner, R.; Kreft, B.; Schnoy, N.; Lajous-Petter, A.M.; Loch, N.; Reutter, W.; Hortsch, M.; Tauber, R. Liver-intestine cadherin: Molecular cloning and characterization of a novel $\mathrm{Ca}(2+)$-dependent cell adhesion molecule expressed in liver and intestine. J. Cell Biol. 1994, 125, 1353-1369. [CrossRef] [PubMed]

15. Jung, R.; Wendeler, M.W.; Danevad, M.; Himmelbauer, H.; Gessner, R. Phylogenetic origin of LI-cadherin revealed by protein and gene structure analysis. Cell Mol. Life Sci. 2004, 61, 1157-1166. [CrossRef] [PubMed]

16. Kreft, B.; Berndorff, D.; Bottinger, A.; Finnemann, S.; Wedlich, D.; Hortsch, M.; Tauber, R.; Gessner, R. LI-cadherin-mediated cell-cell adhesion does not require cytoplasmic interactions. J. Cell Biol. 1997, 136, 1109-1121. [CrossRef] [PubMed]

17. Bartolome, R.A.; Barderas, R.; Torres, S.; Fernandez-Acenero, M.J.; Mendes, M.; Garcia-Foncillas, J.; Lopez-Lucendo, M.; Casal, J.I. Cadherin-17 interacts with alpha2beta1 integrin to regulate cell proliferation and adhesion in colorectal cancer cells causing liver metastasis. Oncogene 2014, 33, 1658-1669. [CrossRef]

18. Cadwell, C.M.; Su, W.; Kowalczyk, A.P. Cadherin tales: Regulation of cadherin function by endocytic membrane trafficking. Traffic 2016, 17, 1262-1271. [CrossRef]

19. Johnson, S.K.; Ramani, V.C.; Hennings, L.; Haun, R.S. Kallikrein 7 enhances pancreatic cancer cell invasion by shedding E-cadherin. Cancer 2007, 109, 1811-1820. [CrossRef]

20. Bartolome, R.A.; Pelaez-Garcia, A.; Gomez, I.; Torres, S.; Fernandez-Acenero, M.J.; Escudero-Paniagua, B.; Imbaud, J.I.; Casal, J.I. An RGD motif present in cadherin 17 induces integrin activation and tumor growth. J. Biol. Chem. 2014, 289, 34801-34814. [CrossRef]

21. Horsfield, J.; Ramachandran, A.; Reuter, K.; LaVallie, E.; Collins-Racie, L.; Crosier, K.; Crosier, P. Cadherin-17 is required to maintain pronephric duct integrity during zebrafish development. Mech. Dev. 2002, 115, 15-26. [CrossRef] 
22. Angres, B.; Kim, L.; Jung, R.; Gessner, R.; Tauber, R. LI-cadherin gene expression during mouse intestinal development. Dev. Dyn. 2001, 221, 182-193. [CrossRef] [PubMed]

23. Baumgartner, W. Possible roles of LI-Cadherin in the formation and maintenance of the intestinal epithelial barrier. Tissue Barriers 2013, 1, e23815. [CrossRef] [PubMed]

24. Baumgartner, W.; Wendeler, M.W.; Weth, A.; Koob, R.; Drenckhahn, D.; Gessner, R. Heterotypic trans-interaction of LI- and E-cadherin and their localization in plasmalemmal microdomains. J. Mol. Biol. 2008, 378, 44-54. [CrossRef] [PubMed]

25. Ahl, M.; Weth, A.; Walcher, S.; Baumgartner, W. The function of 7D-cadherins: A mathematical model predicts physiological importance for water transport through simple epithelia. Biol. Med. Model. 2011, 8, 18. [CrossRef]

26. Bartolmas, T.; Hirschfeld-Ihlow, C.; Jonas, S.; Schaefer, M.; Gessner, R. LI-cadherin cis-dimerizes in the plasma membrane $\mathrm{Ca}(2+)$ independently and forms highly dynamic trans-contacts. Cell Mol. Life Sci. 2012, 69, 3851-3862. [CrossRef] [PubMed]

27. Prevarskaya, N.; Skryma, R.; Shuba, Y. Calcium in tumour metastasis: New roles for known actors. Nat. Rev. Cancer 2011, 11, 609-618. [CrossRef]

28. Tanihara, H.; Kido, M.; Obata, S.; Heimark, R.L.; Davidson, M.; St John, T.; Suzuki, S. Characterization of cadherin-4 and cadherin-5 reveals new aspects of cadherins. J. Cell Sci. 1994, 107, 1697-1704.

29. Hatta, K.; Okada, T.S.; Takeichi, M. A monoclonal antibody disrupting calcium-dependent cell-cell adhesion of brain tissues: Possible role of its target antigen in animal pattern formation. Proc. Natl. Acad. Sci. USA. 1985, 82, 2789-2793. [CrossRef]

30. Corada, M.; Zanetta, L.; Orsenigo, F.; Breviario, F.; Lampugnani, M.G.; Bernasconi, S.; Liao, F.; Hicklin, D.J.; Bohlen, P.; Dejana, E. A monoclonal antibody to vascular endothelial-cadherin inhibits tumor angiogenesis without side effects on endothelial permeability. Blood 2002, 100, 905-911. [CrossRef]

31. Bartolome, R.A.; Torres, S.; Isern de Val, S.; Escudero-Paniagua, B.; Calvino, E.; Teixido, J.; Casal, J.I. VE-cadherin RGD motifs promote metastasis and constitute a potential therapeutic target in melanoma and breast cancers. Oncotarget 2017, 8, 215-227. [CrossRef] [PubMed]

32. Giannotta, M.; Trani, M.; Dejana, E. VE-cadherin and endothelial adherens junctions: Active guardians of vascular integrity. Dev. Cell 2013, 26, 441-454. [CrossRef]

33. Flemming, S.; Burkard, N.; Renschler, M.; Vielmuth, F.; Meir, M.; Schick, M.A.; Wunder, C.; Germer, C.T.; Spindler, V.; Waschke, J.; et al. Soluble VE-cadherin is involved in endothelial barrier breakdown in systemic inflammation and sepsis. Cardiovasc Res. 2015, 107, 32-44. [CrossRef] [PubMed]

34. Dejana, E.; Vestweber, D. The role of VE-cadherin in vascular morphogenesis and permeability control. Prog. Mol. Biol. Transl. Sci. 2013, 116, 119-144. [PubMed]

35. Baumeister, U.; Funke, R.; Ebnet, K.; Vorschmitt, H.; Koch, S.; Vestweber, D. Association of Csk to VE-cadherin and inhibition of cell proliferation. Embo J. 2005, 24, 1686-1695. [CrossRef]

36. Lagendijk, A.K.; Hogan, B.M. VE-cadherin in vascular development: A coordinator of cell signaling and tissue morphogenesis. Curr. Top. Dev. Biol. 2015, 112, 325-352. [PubMed]

37. Cho, E.A.; Patterson, L.T.; Brookhiser, W.T.; Mah, S.; Kintner, C.; Dressler, G.R. Differential expression and function of cadherin-6 during renal epithelium development. Development 1998, 125, 803-812.

38. Mah, S.P.; Saueressig, H.; Goulding, M.; Kintner, C.; Dressler, G.R. Kidney development in cadherin-6 mutants: Delayed mesenchyme-to-epithelial conversion and loss of nephrons. Dev. Biol. 2000, 223, 38-53. [CrossRef]

39. Shimoyama, Y.; Gotoh, M.; Terasaki, T.; Kitajima, M.; Hirohashi, S. Isolation and sequence analysis of human cadherin-6 complementary DNA for the full coding sequence and its expression in human carcinoma cells. Cancer Res. 1995, 55, 2206-2211.

40. Xiang, Y.Y.; Tanaka, M.; Suzuki, M.; Igarashi, H.; Kiyokawa, E.; Naito, Y.; Ohtawara, Y.; Shen, Q.; Sugimura, H.; Kino, I. Isolation of complementary DNA encoding K-cadherin, a novel rat cadherin preferentially expressed in fetal kidney and kidney carcinoma. Cancer Res. 1994, 54, 3034-3041.

41. Stewart, D.B.; Barth, A.I.; Nelson, W.J. Differential regulation of endogenous cadherin expression in Madin-Darby canine kidney cells by cell-cell adhesion and activation of beta -catenin signaling. J. Biol. Chem. 2000, 275, 20707-20716. [CrossRef] [PubMed]

42. Troxell, M.L.; Loftus, D.J.; Nelson, W.J.; Marrs, J.A. Mutant cadherin affects epithelial morphogenesis and invasion, but not transformation. J. Cell Sci. 2001, 114, 1237-1246. [PubMed] 
43. Shimazui, T.; Giroldi, L.A.; Bringuier, P.P.; Oosterwijk, E.; Schalken, J.A. Complex cadherin expression in renal cell carcinoma. Cancer Res. 1996, 56, 3234-3237. [PubMed]

44. Paul, R.; Ewing, C.M.; Robinson, J.C.; Marshall, F.F.; Johnson, K.R.; Wheelock, M.J.; Isaacs, W.B. Cadherin-6, a cell adhesion molecule specifically expressed in the proximal renal tubule and renal cell carcinoma. Cancer Res. 1997, 57, 2741-2748. [CrossRef] [PubMed]

45. Hinoi, T.; Lucas, P.C.; Kuick, R.; Hanash, S.; Cho, K.R.; Fearon, E.R. CDX2 regulates liver intestine-cadherin expression in normal and malignant colon epithelium and intestinal metaplasia. Gastroenterology 2002, 123, 1565-1577. [CrossRef]

46. Silberg, D.G.; Swain, G.P.; Suh, E.R.; Traber, P.G. Cdx1 and cdx2 expression during intestinal development. Gastroenterology 2000, 119, 961-971. [CrossRef]

47. Grotzinger, C.; Kneifel, J.; Patschan, D.; Schnoy, N.; Anagnostopoulos, I.; Faiss, S.; Tauber, R.; Wiedenmann, B.; Gessner, R. LI-cadherin: A marker of gastric metaplasia and neoplasia. Gut 2001, 49, 73-81. [CrossRef]

48. Ito, R.; Oue, N.; Yoshida, K.; Kunimitsu, K.; Nakayama, H.; Nakachi, K.; Yasui, W. Clinicopathological significant and prognostic influence of cadherin-17 expression in gastric cancer. Virchows Arch. Int. J. Pathol. 2005, 447, 717-722. [CrossRef]

49. Takamura, M.; Sakamoto, M.; Ino, Y.; Shimamura, T.; Ichida, T.; Asakura, H.; Hirohashi, S. Expression of liver-intestine cadherin and its possible interaction with galectin-3 in ductal adenocarcinoma of the pancreas. Cancer Sci. 2003, 94, 425-430. [CrossRef]

50. Su, M.C.; Yuan, R.H.; Lin, C.Y.; Jeng, Y.M. Cadherin-17 is a useful diagnostic marker for adenocarcinomas of the digestive system. Mod. Pathol. 2008, 21, 1379-1386. [CrossRef]

51. Kuhlmann, L.; Nadler, W.M.; Kerner, A.; Hanke, S.A.; Noll, E.M.; Eisen, C.; Espinet, E.; Vogel, V.; Trumpp, A.; Sprick, M.R.; et al. Identification and Validation of Novel Subtype-Specific Protein Biomarkers in Pancreatic Ductal Adenocarcinoma. Pancreas 2017, 46, 311-322. [CrossRef] [PubMed]

52. Srivastava, S.; Kern, F.; Sharma, N.; McKeon, F.; Xian, W.; Yeoh, K.G.; Ho, K.Y.; Teh, M. FABP1 and Hepar expression levels in Barrett's esophagus and associated neoplasia in an Asian population. Dig. Liver Dis. 2017, 49, 1104-1109. [CrossRef] [PubMed]

53. Snow, A.N.; Mangray, S.; Lu, S.; Clubwala, R.; Li, J.; Resnick, M.B.; Yakirevich, E. Expression of cadherin 17 in well-differentiated neuroendocrine tumours. Histopathology 2015, 66, 1010-1021. [CrossRef] [PubMed]

54. Johnson, A.; Wright, J.P.; Zhao, Z.; Komaya, T.; Parikh, A.; Merchant, N.; Shi, C. Cadherin 17 is frequently expressed by 'sclerosing variant' pancreatic neuroendocrine tumour. Histopathology 2015, 66, 225-233. [CrossRef] [PubMed]

55. Park, J.H.; Seol, J.A.; Choi, H.J.; Roh, Y.H.; Choi, P.J.; Lee, K.E.; Roh, M.S. Comparison of cadherin-17 expression between primary colorectal adenocarcinomas and their corresponding metastases: The possibility of a diagnostic marker for detecting the primary site of metastatic tumour. Histopathology 2011, 58, 315-318. [CrossRef] [PubMed]

56. Ordonez, N.G. Cadherin 17 is a novel diagnostic marker for adenocarcinomas of the digestive system. Adv. Anat. Pathol. 2014, 21, 131-137. [CrossRef] [PubMed]

57. Liu, L.X.; Lee, N.P.; Chan, V.W.; Xue, W.; Zender, L.; Zhang, C.; Mao, M.; Dai, H.; Wang, X.L.; Xu, M.Z.; et al. Targeting cadherin-17 inactivates Wnt signaling and inhibits tumor growth in liver carcinoma. Hepatology 2009, 50, 1453-1463. [CrossRef]

58. Wong, B.W.; Luk, J.M.; Ng, I.O.; Hu, M.Y.; Liu, K.D.; Fan, S.T. Identification of liver-intestine cadherin in hepatocellular carcinoma-a potential disease marker. Biochem. Biophys. Res. Commun. 2003, 311, 618-624. [CrossRef]

59. Ding, Z.B.; Shi, Y.H.; Zhou, J.; Shi, G.M.; Ke, A.W.; Qiu, S.J.; Wang, X.Y.; Dai, Z.; Xu, Y.; Fan, J. Liver-intestine cadherin predicts microvascular invasion and poor prognosis of hepatitis B virus-positive hepatocellular carcinoma. Cancer 2009, 115, 4753-4765. [CrossRef]

60. Altree-Tacha, D.; Tyrrell, J.; Haas, T. CDH17 Is a More Sensitive Marker for Gastric Adenocarcinoma Than CK20 and CDX2. Arch. Pathol. Lab. Med. 2017, 141, 144-150. [CrossRef]

61. Huang, L.P.; Yu, Y.H.; Sheng, C.; Wang, S.H. Up-regulation of cadherin 17 and down-regulation of homeodomain protein CDX2 correlate with tumor progression and unfavorable prognosis in epithelial ovarian cancer. Int. J. Gynecol. Cancer 2012, 22, 1170-1176. [CrossRef] [PubMed] 
62. Heinzelmann-Schwarz, V.A.; Gardiner-Garden, M.; Henshall, S.M.; Scurry, J.P.; Scolyer, R.A.; Smith, A.N.; Bali, A.; Vanden Bergh, P.; Baron-Hay, S.; Scott, C.; et al. A distinct molecular profile associated with mucinous epithelial ovarian cancer. Br. J. Cancer 2006, 94, 904-913. [CrossRef] [PubMed]

63. Uhlen, M.; Zhang, C.; Lee, S.; Sjostedt, E.; Fagerberg, L.; Bidkhori, G.; Benfeitas, R.; Arif, M.; Liu, Z.; Edfors, F.; et al. A pathology atlas of the human cancer transcriptome. Science 2017, 357. [CrossRef] [PubMed]

64. Rao, Q.; Williamson, S.R.; Lopez-Beltran, A.; Montironi, R.; Huang, W.; Eble, J.N.; Grignon, D.J.; Koch, M.O.; Idrees, M.T.; Emerson, R.E.; et al. Distinguishing primary adenocarcinoma of the urinary bladder from secondary involvement by colorectal adenocarcinoma: Extended immunohistochemical profiles emphasizing novel markers. Mod. Pathol. 2013, 26, 725-732. [CrossRef] [PubMed]

65. Torres, S.; Garcia-Palmero, I.; Bartolome, R.A.; Fernandez-Acenero, M.J.; Molina, E.; Calvino, E.; Segura, M.F.; Casal, J.I. Combined miRNA profiling and proteomics demonstrates that different miRNAs target a common set of proteins to promote colorectal cancer metastasis. J. Pathol. 2017, 242, 39-51. [CrossRef] [PubMed]

66. Wang, J.; Kang, W.M.; Yu, J.C.; Liu, Y.Q.; Meng, Q.B.; Cao, Z.J. Cadherin-17 induces tumorigenesis and lymphatic metastasis in gastric cancer through activation of NFkappaB signaling pathway. Cancer Biol. 2013, 14, 262-270. [CrossRef] [PubMed]

67. Jiang, X.J.; Lin, J.; Cai, Q.H.; Zhao, J.F.; Zhang, H.J. CDH17 alters MMP-2 expression via canonical NF-kappaB signalling in human gastric cancer. Gene 2019, 682, 92-100. [CrossRef]

68. Yoshimura, K.; Meckel, K.F.; Laird, L.S.; Chia, C.Y.; Park, J.J.; Olino, K.L.; Tsunedomi, R.; Harada, T.; Iizuka, N.; Hazama, S.; et al. Integrin alpha2 mediates selective metastasis to the liver. Cancer Res. 2009, 69, 7320-7328. [CrossRef]

69. Hendrix, M.J.; Seftor, E.A.; Meltzer, P.S.; Gardner, L.M.; Hess, A.R.; Kirschmann, D.A.; Schatteman, G.C.; Seftor, R.E. Expression and functional significance of VE-cadherin in aggressive human melanoma cells: Role in vasculogenic mimicry. Proc. Natl. Acad. Sci. USA 2001, 98, 8018-8023. [CrossRef]

70. Hendrix, M.J.; Seftor, E.A.; Hess, A.R.; Seftor, R.E. Vasculogenic mimicry and tumour-cell plasticity: Lessons from melanoma. Nat. Rev. Cancer 2003, 3, 411-421. [CrossRef]

71. Wang, R.; Chadalavada, K.; Wilshire, J.; Kowalik, U.; Hovinga, K.E.; Geber, A.; Fligelman, B.; Leversha, M.; Brennan, C.; Tabar, V. Glioblastoma stem-like cells give rise to tumour endothelium. Nature 2010, 468, 829-833. [CrossRef] [PubMed]

72. Cao, Z.; Bao, M.; Miele, L.; Sarkar, F.H.; Wang, Z.; Zhou, Q. Tumour vasculogenic mimicry is associated with poor prognosis of human cancer patients: A systemic review and meta-analysis. Eur. J. Cancer 2013, 49, 3914-3923. [CrossRef] [PubMed]

73. Yue, W.Y.; Chen, Z.P. Does vasculogenic mimicry exist in astrocytoma? J. Histochem Cytochem 2005, 53, 997-1002. [CrossRef] [PubMed]

74. Sun, B.; Zhang, S.; Zhao, X.; Zhang, W.; Hao, X. Vasculogenic mimicry is associated with poor survival in patients with mesothelial sarcomas and alveolar rhabdomyosarcomas. Int. J. Oncol. 2004, 25, 1609-1614. [CrossRef] [PubMed]

75. van der Schaft, D.W.; Hillen, F.; Pauwels, P.; Kirschmann, D.A.; Castermans, K.; Egbrink, M.G.; Tran, M.G.; Sciot, R.; Hauben, E.; Hogendoorn, P.C.; et al. Tumor cell plasticity in Ewing sarcoma, an alternative circulatory system stimulated by hypoxia. Cancer Res. 2005, 65, 11520-11528. [CrossRef] [PubMed]

76. Wang, L.; O'Leary, H.; Fortney, J.; Gibson, L.F. Ph+/VE-cadherin+ identifies a stem cell like population of acute lymphoblastic leukemia sustained by bone marrow niche cells. Blood 2007, 110, 3334-3344. [CrossRef] [PubMed]

77. Akers, S.M.; O’Leary, H.A.; Minnear, F.L.; Craig, M.D.; Vos, J.A.; Coad, J.E.; Gibson, L.F. VE-cadherin and PECAM-1 enhance ALL migration across brain microvascular endothelial cell monolayers. Exp. Hematol. 2010, 38, 733-743. [CrossRef]

78. Chen, C.; Zhang, H.X.; Wang, M.; Song, X.G.; Cao, J.; Wang, L.; Qiao, J.L.; Lu, X.Y.; Han, Z.X.; Zhu, P.; et al. Stromal cells attenuate the cytotoxicity of imatinib on Philadelphia chromosome-positive leukemia cells by up-regulating the VE-cadherin/beta-catenin signal. Leuk Res. 2014, 38, 1460-1468. [CrossRef]

79. Hung, M.S.; Chen, I.C.; Lung, J.H.; Lin, P.Y.; Li, Y.C.; Tsai, Y.H. Epidermal Growth Factor Receptor Mutation Enhances Expression of Cadherin-5 in Lung Cancer Cells. PLos One 2016, 11, e0158395. [CrossRef]

80. Bittner, M.; Meltzer, P.; Chen, Y.; Jiang, Y.; Seftor, E.; Hendrix, M.; Radmacher, M.; Simon, R.; Yakhini, Z.; Ben-Dor, A.; et al. Molecular classification of cutaneous malignant melanoma by gene expression profiling. Nature 2000, 406, 536-540. [CrossRef] 
81. Rochefort, P.; Chabaud, S.; Pierga, J.Y.; Tredan, O.; Brain, E.; Bidard, F.C.; Schiffler, C.; Polena, H.; Khalil-Mgharbel, A.; Vilgrain, I.; et al. Soluble VE-cadherin in metastatic breast cancer: An independent prognostic factor for both progression-free survival and overall survival. Br. J. Cancer 2017, 116, 356-361. [CrossRef] [PubMed]

82. Fry, S.A.; Robertson, C.E.; Swann, R.; Dwek, M.V. Cadherin-5: A biomarker for metastatic breast cancer with optimum efficacy in oestrogen receptor-positive breast cancers with vascular invasion. Br. J. Cancer 2016, 114, 1019-1026. [CrossRef] [PubMed]

83. Speisky, D.; Duces, A.; Bieche, I.; Rebours, V.; Hammel, P.; Sauvanet, A.; Richard, S.; Bedossa, P.; Vidaud, M.; Murat, A.; et al. Molecular profiling of pancreatic neuroendocrine tumors in sporadic and Von Hippel-Lindau patients. Clin. Cancer Res. 2012, 18, 2838-2849. [CrossRef] [PubMed]

84. Higuchi, K.; Inokuchi, M.; Takagi, Y.; Ishikawa, T.; Otsuki, S.; Uetake, H.; Kojima, K.; Kawano, T. Cadherin 5 expression correlates with poor survival in human gastric cancer. J. Clin. Pathol. 2017, 70, 217-221. [CrossRef] [PubMed]

85. Loges, S.; Clausen, H.; Reichelt, U.; Bubenheim, M.; Erbersdobler, A.; Schurr, P.; Yekebas, E.; Schuch, G.; Izbicki, J.; Pantel, K.; et al. Determination of microvessel density by quantitative real-time PCR in esophageal cancer: Correlation with histologic methods, angiogenic growth factor expression, and lymph node metastasis. Clin. Cancer Res. 2007, 13, 76-80. [CrossRef] [PubMed]

86. Labelle, M.; Schnittler, H.J.; Aust, D.E.; Friedrich, K.; Baretton, G.; Vestweber, D.; Breier, G. Vascular endothelial cadherin promotes breast cancer progression via transforming growth factor beta signaling. Cancer Res. 2008, 68, 1388-1397. [CrossRef] [PubMed]

87. Hess, A.R.; Seftor, E.A.; Gruman, L.M.; Kinch, M.S.; Seftor, R.E.; Hendrix, M.J. VE-cadherin regulates EphA2 in aggressive melanoma cells through a novel signaling pathway: Implications for vasculogenic mimicry. Cancer Biol. 2006, 5, 228-233. [CrossRef] [PubMed]

88. Mao, X.G.; Xue, X.Y.; Wang, L.; Zhang, X.; Yan, M.; Tu, Y.Y.; Lin, W.; Jiang, X.F.; Ren, H.G.; Zhang, W.; et al. CDH5 is specifically activated in glioblastoma stemlike cells and contributes to vasculogenic mimicry induced by hypoxia. Neuro. Oncol. 2013, 15, 865-879. [CrossRef]

89. Paul, R.; Necknig, U.; Busch, R.; Ewing, C.M.; Hartung, R.; Isaacs, W.B. Cadherin-6: A new prognostic marker for renal cell carcinoma. J. Urol. 2004, 171, 97-101. [CrossRef]

90. Kobel, M.; Kalloger, S.E.; Boyd, N.; McKinney, S.; Mehl, E.; Palmer, C.; Leung, S.; Bowen, N.J.; Ionescu, D.N.; Rajput, A.; et al. Ovarian carcinoma subtypes are different diseases: Implications for biomarker studies. PLoS Med. 2008, 5, e232. [CrossRef]

91. Sellar, G.C.; Li, L.; Watt, K.P.; Nelkin, B.D.; Rabiasz, G.J.; Stronach, E.A.; Miller, E.P.; Porteous, D.J.; Smyth, J.F.; Gabra, H. BARX2 induces cadherin 6 expression and is a functional suppressor of ovarian cancer progression. Cancer Res. 2001, 61, 6977-6981. [PubMed]

92. Puxeddu, E.; Knauf, J.A.; Sartor, M.A.; Mitsutake, N.; Smith, E.P.; Medvedovic, M.; Tomlinson, C.R.; Moretti, S.; Fagin, J.A. RET/PTC-induced gene expression in thyroid PCCL3 cells reveals early activation of genes involved in regulation of the immune response. Endocr. Relat. Cancer 2005, 12, 319-334. [CrossRef] [PubMed]

93. Zhao, L.; Jiang, R.; Xu, M.; Zhu, P.; Mo, X.M.; Wang, N.; Chen, G.G.; Liu, Z.M. Concomitant high expression of BRAFV600E, P-cadherin and cadherin 6 is associated with High TNM stage and lymph node metastasis in conventional papillary thyroid carcinoma. Clin. Endocrinol. (Oxf) 2016, 84, 748-755. [CrossRef] [PubMed]

94. Goeppert, B.; Ernst, C.; Baer, C.; Roessler, S.; Renner, M.; Mehrabi, A.; Hafezi, M.; Pathil, A.; Warth, A.; Stenzinger, A.; et al. Cadherin-6 is a putative tumor suppressor and target of epigenetically dysregulated miR-429 in cholangiocarcinoma. Epigenetics 2016, 11, 780-790. [CrossRef] [PubMed]

95. Ji, Q.; Xu, X.; Song, Q.; Xu, Y.; Tai, Y.; Goodman, S.B.; Bi, W.; Xu, M.; Jiao, S.; Maloney, W.J.; et al. miR-223-3p Inhibits Human Osteosarcoma Metastasis and Progression by Directly Targeting CDH6. Mol. Ther. 2018, 26, 1299-1312. [CrossRef]

96. Ciarrocchi, A.; Piana, S.; Valcavi, R.; Gardini, G.; Casali, B. Inhibitor of DNA binding-1 induces mesenchymal features and promotes invasiveness in thyroid tumour cells. Eur. J. Cancer 2011, 47, 934-945. [CrossRef]

97. Zuo, L.L.; Zhang, J.; Liu, L.Z.; Zhou, Q.; Du, S.J.; Xin, S.Y.; Ning, Z.P.; Yang, J.; Yu, H.B.; Yue, W.X.; et al. Cadherin 6 is activated by Epstein-Barr virus LMP1 to mediate EMT and metastasis as an interplay node of multiple pathways in nasopharyngeal carcinoma. Oncogenesis 2017, 6, 402. [CrossRef] 
98. Bialucha, C.U.; Collins, S.D.; Li, X.; Saxena, P.; Zhang, X.; Durr, C.; Lafont, B.; Prieur, P.; Shim, Y.; Mosher, R.; et al. Discovery and Optimization of HKT288, a Cadherin-6-Targeting ADC for the Treatment of Ovarian and Renal Cancers. Cancer Discov. 2017, 7, 1030-1045. [CrossRef]

99. de Cristofaro, T.; Di Palma, T.; Soriano, A.A.; Monticelli, A.; Affinito, O.; Cocozza, S.; Zannini, M. Candidate genes and pathways downstream of PAX8 involved in ovarian high-grade serous carcinoma. Oncotarget 2016, 7, 41929-41947. [CrossRef]

100. Yang, C.; Zhao, X.; Cui, N.; Liang, Y. Cadherins Associate with Distinct Stem Cell-Related Transcription Factors to Coordinate the Maintenance of Stemness in Triple-Negative Breast Cancer. Stem Cells Int. 2017, 2017, 5091541. [CrossRef]

101. Sancisi, V.; Gandolfi, G.; Ragazzi, M.; Nicoli, D.; Tamagnini, I.; Piana, S.; Ciarrocchi, A. Cadherin 6 is a new RUNX2 target in TGF-beta signalling pathway. PLos One 2013, 8, e75489. [CrossRef] [PubMed]

102. Gugnoni, M.; Sancisi, V.; Gandolfi, G.; Manzotti, G.; Ragazzi, M.; Giordano, D.; Tamagnini, I.; Tigano, M.; Frasoldati, A.; Piana, S.; et al. Cadherin-6 promotes EMT and cancer metastasis by restraining autophagy. Oncogene 2017, 36, 667-677. [CrossRef] [PubMed]

103. Dunne, E.; Spring, C.M.; Reheman, A.; Jin, W.; Berndt, M.C.; Newman, D.K.; Newman, P.J.; Ni, H.; Kenny, D. Cadherin 6 has a functional role in platelet aggregation and thrombus formation. Arter. Thromb. Vasc. Biol. 2012, 32, 1724-1731. [CrossRef] [PubMed]

104. Reiss, S.; Sieber, M.; Oberle, V.; Wentzel, A.; Spangenberg, P.; Claus, R.; Kolmar, H.; Losche, W. Inhibition of platelet aggregation by grafting RGD and KGD sequences on the structural scaffold of small disulfide-rich proteins. Platelets 2006, 17, 153-157. [CrossRef] [PubMed]

105. Sanchez-Cortes, J.; Mrksich, M. The platelet integrin alphaIlbbeta3 binds to the RGD and AGD motifs in fibrinogen. Chem. Biol. 2009, 16, 990-1000. [CrossRef] [PubMed]

106. Naci, D.; Vuori, K.; Aoudjit, F. Alpha2beta1 integrin in cancer development and chemoresistance. Semin. Cancer Biol. 2015, 35, 145-153. [CrossRef] [PubMed]

107. Hynes, R.O. Integrins: Bidirectional, allosteric signaling machines. Cell 2002, 110, 673-687. [CrossRef]

108. Desgrosellier, J.S.; Cheresh, D.A. Integrins in cancer: Biological implications and therapeutic opportunities. Nat. Rev. Cancer 2010, 10, 9-22. [CrossRef]

109. Seguin, L.; Desgrosellier, J.S.; Weis, S.M.; Cheresh, D.A. Integrins and cancer: Regulators of cancer stemness, metastasis, and drug resistance. Trends Cell Biol. 2015, 25, 234-240. [CrossRef]

110. Casal, J.I.; Bartolome, R.A. RGD cadherins and alpha2beta1 integrin in cancer metastasis: A dangerous liaison. Biochim. Biophys. Acta Rev. Cancer 2018, 1869, 321-332. [CrossRef]

111. Weber, G.F.; Bjerke, M.A.; DeSimone, D.W. Integrins and cadherins join forces to form adhesive networks. J. Cell Sci. 2011, 124, 1183-1193. [CrossRef] [PubMed]

112. Canonici, A.; Steelant, W.; Rigot, V.; Khomitch-Baud, A.; Boutaghou-Cherid, H.; Bruyneel, E.; Van Roy, F.; Garrouste, F.; Pommier, G.; Andre, F. Insulin-like growth factor-I receptor, E-cadherin and alpha v integrin form a dynamic complex under the control of alpha-catenin. Int. J. Cancer 2008, 122, 572-582. [CrossRef] [PubMed]

113. Hintermann, E.; Yang, N.; O'Sullivan, D.; Higgins, J.M.; Quaranta, V. Integrin alpha6beta4-erbB2 complex inhibits haptotaxis by up-regulating E-cadherin cell-cell junctions in keratinocytes. J. Biol. Chem. 2005, 280, 8004-8015. [CrossRef]

114. Siret, C.; Terciolo, C.; Dobric, A.; Habib, M.C.; Germain, S.; Bonnier, R.; Lombardo, D.; Rigot, V.; Andre, F. Interplay between cadherins and alpha2beta1 integrin differentially regulates melanoma cell invasion. Br. J. Cancer 2015, 113, 1445-1453. [CrossRef] [PubMed]

115. Song, S.; Mazurek, N.; Liu, C.; Sun, Y.; Ding, Q.Q.; Liu, K.; Hung, M.C.; Bresalier, R.S. Galectin-3 mediates nuclear beta-catenin accumulation and Wnt signaling in human colon cancer cells by regulation of glycogen synthase kinase-3beta activity. Cancer Res. 2009, 69, 1343-1349. [CrossRef]

116. Weichert, W.; Knosel, T.; Bellach, J.; Dietel, M.; Kristiansen, G. ALCAM/CD166 is overexpressed in colorectal carcinoma and correlates with shortened patient survival. J. Clin. Pathol. 2004, 57, 1160-1164. [CrossRef] [PubMed]

117. Van Kempen, L.C.; van den Oord, J.J.; van Muijen, G.N.; Weidle, U.H.; Bloemers, H.P.; Swart, G.W. Activated leukocyte cell adhesion molecule/CD166, a marker of tumor progression in primary malignant melanoma of the skin. Am. J. Pathol. 2000, 156, 769-774. [CrossRef] 
118. Eiring, A.M.; Khorashad, J.S.; Anderson, D.J.; Yu, F.; Redwine, H.M.; Mason, C.C.; Reynolds, K.R.; Clair, P.M.; Gantz, K.C.; Zhang, T.Y.; et al. beta-Catenin is required for intrinsic but not extrinsic BCR-ABL1 kinase-independent resistance to tyrosine kinase inhibitors in chronic myeloid leukemia. Leukemia 2015, 29, 2328-2337. [CrossRef]

119. Williams, E.; Williams, G.; Gour, B.J.; Blaschuk, O.W.; Doherty, P. A novel family of cyclic peptide antagonists suggests that $\mathrm{N}$-cadherin specificity is determined by amino acids that flank the HAV motif. J. Biol. Chem. 2000, 275, 4007-4012. [CrossRef]

120. Kelland, L. Drug evaluation: ADH-1, an N-cadherin antagonist targeting cancer vascularization. Curr. Opin. Mol. 2007, 9, 86-91.

121. Bartolome, R.A.; Aizpurua, C.; Jaen, M.; Torres, S.; Calvino, E.; Imbaud, J.I.; Casal, J.I. Monoclonal Antibodies Directed against Cadherin RGD Exhibit Therapeutic Activity against Melanoma and Colorectal Cancer Metastasis. Clin. Cancer Res. 2018, 24, 433-444. [CrossRef] [PubMed]

122. Beasley, G.M.; Riboh, J.C.; Augustine, C.K.; Zager, J.S.; Hochwald, S.N.; Grobmyer, S.R.; Peterson, B.; Royal, R.; Ross, M.I.; Tyler, D.S. Prospective multicenter phase II trial of systemic ADH-1 in combination with melphalan via isolated limb infusion in patients with advanced extremity melanoma. J. Clin. Oncol. 2011, 29, 1210-1215. [CrossRef] [PubMed]

(C) 2019 by the authors. Licensee MDPI, Basel, Switzerland. This article is an open access article distributed under the terms and conditions of the Creative Commons Attribution (CC BY) license (http://creativecommons.org/licenses/by/4.0/). 